\title{
Teenage Pregnancy in South African Schools: Challenges, Trends and Policy Issues
}

\author{
Mashudu R. Ramulumo \\ Victor J. Pitsoe \\ Department of Educational Management and Leadership, \\ College of Education, \\ University of South Africa \\ E-mail address: Pitsovj@unisa.ac.za
}

Doi:10.5901/mjss.2013.v4n13p755

\begin{abstract}
Teenage pregnancy in South African schools poses a serious management and leadership challenge. It calls for school management teams (SMTs) to acquire critical skills to manage teenage pregnancy within the requirements of the Constitution of the Republic of South Africa, 1996 and the South African Schools Act 84 of 1996. Little, if any, research has been conducted on learner pregnancy as a hurdle toward the achievement of millennium development goals (MDGs) and EFA goals. Drawing on literature, this article will (1) explore policy on teenage pregnancy from a South African perspective; (2) look into the trends and challenges of teenage pregnancy in a schooling context; (3) reflect on policy implications of teenage pregnancy in a schooling context; and (4) capture information on teenage pregnancy in schools as it relates to MDGs and EFA goals.
\end{abstract}

Keywords: teenage pregnancy, school management teams, MDGs and EFA goals

\section{Introduction}

Teenage pregnancy poses a challenge to global society. Despite the birth rate among teenagers climbing after having dropped slowly for years, the estimate of teenage pregnancies in developed countries falls into millions. A significant number of these pregnancies are unplanned, which in any population can raise certain challenges. It has been more than a decade since the South African Schools Act 84 of 1996 forbade discrimination in schools on the basis of pregnancy. However, while the law is clear that such learners cannot be turned away from school, it is less clear how schools should deal with pregnant learners and learner-parents (Bhana, Clowes, Morrell \& Shefer 2008:78). In terms of Article 9(3) of the Constitution of the Republic of South Africa, 1996, the state may not unfairly discriminate, whether directly or indirectly, against anyone on one or more grounds, including race, gender, sexual inclination and pregnancy. Every child irrespective of colour and creed has the right to education.

As Gustafsson and Worku (2007:2) observe, there is a high rate of teenage childbearing in South Africa. The United States, Turkey and Brazil have similar levels of around thousands of women giving birth during their teenage years. This suggests that teenage pregnancy is a global social problem which affects both developing and developed countries. Teenage parenthood is the number one reason that girls drop out of school. When school administrators impede pregnant and parenting students' access to education, they contribute to these dropout rates, even though some girls can't keep up at school and then drop out anyway (McNeely 2007:269). This implies that school principals contribute in denying pregnant teenagers their right to education. Majavu (2009) reports that days after teenage experts told parliament that teenage mothers should be kept at school, a Cape Town principal stood accused of suspending pregnant school learners and not allowing them back after they had given birth (Sowetan Live, 2009: online).

The grim realities of teenage pregnancy in South Africa are not pleasant, and they do have far-reaching implications. Among others, it poses a serious management and leadership challenge. It calls for the school management teams (SMTs) to acquire critical skills to manage teenage pregnancy within the provisions of the Constitution of the Republic of South Africa, 1996 and the South African Schools Act 84 of 1996. In addition, teenage pregnancy has huge global policy inferences. Much has been written about sexual education. Little if any research has been conducted on learner pregnancy as a hurdle toward the achievement of MDGs and EFA goals. Drawing on literature this article (1) explores policy on teenage pregnancy from a South African perspective; (2) looks into the trends and challenges of teenage pregnancy in a schooling context; (3) reflects on policy implications of teenage pregnancy in a schooling context; and (4) examines teenage pregnancy in schools against MDGs and EFA goals. 


\section{Policy on teenage pregnancy: South African perspective}

The Department of Education's (2007:3) Policy on Measures for the Prevention and Management of Learner Pregnancy outline a range of measures to prevent early pregnancy and to manage it when it does occur. According to the Department of Education's Policy on Measures for the Prevention and management of Learner Pregnancy (2007:7), the Provincial Education Department must provide every school with a copy of these measures, and ensure their compliance. They should also strive to ensure educators and managers are equipped to deal with the many challenges related to learner pregnancy. Schools should also ensure that parents are adequately informed about these measures.

Mngoma (2010) reports that pregnancy among teenage pupils is still a huge challenge for many local schools that believe they are fighting a losing battle, with some reporting as many as 20 pregnant teenagers in their schools each year (The Witness, 2010: online). This happens despite all the campaigns that are launched on sex education and even teachings in life orientation at school. In the executive summary of their research, Macleod and Tracy (2009:VI) indicated that capacity at provincial and district level is identified as an obstacle to implementation in general, and that educators as well as district and provincial level coordinators and management experience a lack of resources that impinge on interventions. This leaves educators together with SMTs with few or no options for how to deal with teenage pregnancy at school.

Some of the school managers are not aware of or are either ignorant of the policy and guidelines of the Department of Education when it comes to teenage pregnancy. Majavu (2009) reports that the principal of Rosendal High School suspended between seven and 20 pregnant pupils from school - some before their pregnancies even became visible. He said that girls can't be running around the school because they might get hurt (Sowetan Live, 2009: online). The challenge that principals of schools face is how to handle pregnant learners. In this case the principal is violating the Constitution of the Republic of South Africa and the South African Schools Act which allow teenagers rights to education irrespective of pregnancy.

Hlungwani (2011) reported in Sowetan Live that pupils at Mavalani Secondary School outside Giyani, Limpopo, went on rampage, destroying property after accusing the principal of reporting that 57 of their schoolmates were pregnant and the youngest expectant mother was 13 years old (Sowetan Live, 2011: online). This confirms the high rate of pregnancy among teenagers who are still at school. It further suggests that parents and educators may be failing in curbing teenage pregnancy. Principals face this challenge of teenage pregnancy daily. African school girls in particular are under pressure. In a context of fragmented family structures, where parents are either absent or working and living in urban areas and where schools offer no support for childcare, they bear the burden of baby care and their school work suffers, although not all African school girls experience the same difficulties (Bhana et al., 2008:85). This implies that lack of parental care may lead to teenage pregnancy. And according to Bhana et al. (2008:88), principals of schools do not even have the skills and capacity to deal with pregnant learners; hence they encourage learners to resume schooling after giving birth. Even though the government and the Department of Education in particular are doing their utmost to curb and reduce the number of pregnant teenagers attending school, the number is increasing yearly.

\section{Trends and challenges of teenage pregnancy in a schooling context}

Much concern has been expressed in recent years, particularly in the media, concerning the perceived increase in pregnancies among teenagers. Many of these reports have been based on localised data (Macleod \& Tracy, 2009:7). Mthethwa (2011: online) reports that teenage pregnancy is a menace to our society. It is a struggle that needs to receive as much attention and focus as the struggle against apartheid, and more recently HIV, received. Teenage pregnancy in the school context is a cause for concern for SMTs. SMTs have challenges that are always on the increase because the Department of Education has left everything in the hands of the school principal. No nurses are on standby should a learner go into labour at school.

Grant and Hallman (2008:369) note that in South Africa national data shows that one in five 18-year-old women has given birth, and more than $40 \%$ have become mothers by the age of 20 . This suggests that a high number of female learners drop out from secondary school as a result of being parents. Cassell (as cited by Panday, Makiwane, Ranchod \& Letsoalo 2009:52) argues that studies in the US have shown that child-rearing, lack of parental support and lack of support from peers all contribute to high dropout rates. Even though the law allows pregnant learners to continue learning at school, some of them decide to stay at home.

Recent research (Panday et al., 2009:20) indicates that the Free State, Gauteng and North West provinces had lower rates of teenage fertility while Mpumalanga, Northern Cape, Limpopo and the Eastern Cape reported high levels of early pregnancy. Nationally, $24.4 \%$ of the girls surveyed in the same study in 2008 admitted to having been pregnant. 
This was 5.3\% more than when the study was conducted six years earlier. Mngoma (2010) reported that in 2002 KwaZulu-Natal accounted for $21.8 \%$ of the interviewed girls who admitted to falling pregnant, while the figure stood at 25.8\% in 2008 (The Witness, 2010: online). Pregnancy among teenage learners appears to be a significant challenge for many local schools. Moselakgomo and Khumalo (Sowetan Live 2011: online) reported that a Mpumalanga school that made headlines last year after 70 of its learners fell pregnant is one of the schools that performed well. The school is said to have performed well because the results have improved, but these were still below $50 \%$ which makes it a dysfunctional school.

Moselakgomo (2010) also reports that Malatse High School in Marapyane, KwaZulu-Natal has a total of 290 girls and 70 of them are expecting (Sowetan Live 2010: online). This is $24 \%$ of girls at that school and it is a high number of learners. According to Zondo (2006:1), adolescent fertility has become considerably more problematic today than in the past. This suggests that more teenagers are becoming pregnant now than in the past. In light of the above, the issue of teenage pregnancy needs to be handled with caution at school. The stakeholders at school who are parents, educators and more specifically school management teams (SMTs) should have the know-how to manage and deal with teenage pregnancy. In their research Berry and Hall (2010:1) found that the highest percentage of girls aged between 15 and 19 years who were pregnant in 2003 were in the Limpopo province at 16.6\%. Even though there was a decline in teenage pregnancy from 1998 to 2003, Limpopo remained at the top. Limpopo consists of mainly rural communities. It has five municipal districts of which Vhembe is one. Most parents in this district work on the reef, leaving their children on their own.

Agence France-Presse reported a general increase in teenage pregnancy in South Africa from 2004 to 2008. Figure 1 below capture the details:

Figure 1: Teenage pregnancy rate in South Africa

(Adapted from: Agence France-Presse)

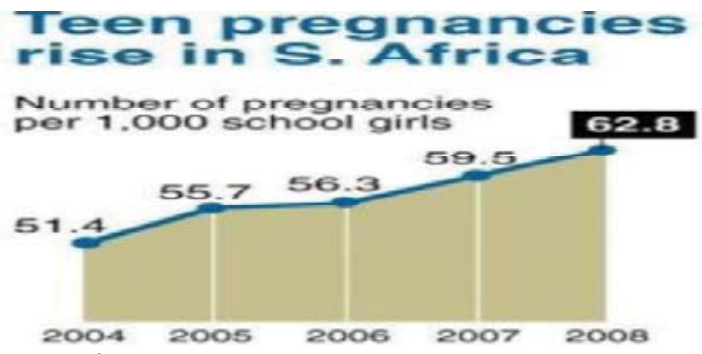

In addition, a significant number of research suggests that:

- The incidence of teenage pregnancy is growing, according to the Human Science Research Council (HSRC), a government think-tank.

- Out of every 1000 girls in school in 2004, 51 were pregnant. This number jumped to 62 in 2008 , the most recent data available.

- This is still low compared to the rest of the continent, where UNICEF says the comparative figure is over 100 in countries such as Nigeria, Uganda, Somalia and Swaziland. In Italy it is seven (AFP, 2011: online).

- Macleod and Tracey (2009:8) indicate in their research that the rate of teenage fertility is lower in South Africa than the overall rate in sub-Saharan Africa. It is comparable to many middle-income countries, but higher than most European countries.

- In her report, Franzcog (2006:25) says that Australia has the third-highest rate of teenage pregnancy in the developed world, following the United States and the United Kingdom.

- The table below gives the national perspective of percentages of teenage girls (15-19) who have ever been pregnant for the years 1998 and 2003.

The table below presents percentages of teenage girls between 1998 and 2003. 
Table 1: Percentage of teenage girls (15-19) who have ever been pregnant

(Adapted from: Hall \& Berry, 2009:1)

\begin{tabular}{|l|l|l|}
\hline Province & $\mathbf{1 9 9 8}$ & $\mathbf{2 0 0 3}$ \\
\hline Eastern Cape & $18 \%$ & $14 \%$ \\
\hline Free State & $13 \%$ & $15 \%$ \\
\hline Gauteng & $10 \%$ & $12 \%$ \\
\hline KwaZulu-Natal & $17 \%$ & $2 \%$ \\
\hline Limpopo & $20 \%$ & $17 \%$ \\
\hline Mpumalanga & $25 \%$ & $13 \%$ \\
\hline North West & $13 \%$ & $14 \%$ \\
\hline Northern Cape & $18 \%$ & $15 \%$ \\
\hline Western Cape & $16 \%$ & $14 \%$ \\
\hline South Africa & $16 \%$ & $\mathbf{1 2} \%$ \\
\hline
\end{tabular}

The Limpopo province had the highest number of teenage pregnancies in 2003. In 1998 it was second to Mpumalanga. Both these provinces are more rural and they also produce the lowest Grade 12 results annually. Teenage pregnancy may be one of the factors contributing to the failure rate. According to the Department of Basic Education in South Africa, Limpopo obtained 57.9\% for Grade 12 results in 2010, up from 48.9\% in 2009; Mpumalanga reached 56.8\% in 2010, up from $47.9 \%$ in 2009: this is an improvement of $8.9 \%$. It triggers a need for training SMTs in how to deal with pregnant learners at school because some principals tend to discourage learners from continuing with school when they are pregnant with the reason being that they are afraid to face the situation where a learner may give birth at school.

\section{Policy implications of teenage pregnancy in a schooling context}

While a liberal school policy on teenage pregnancy has softened some of the consequences of early childbearing in South Africa, not all teenage mothers remain in school or return to school. This may stem from an uneven implementation of school policy, resulting in the suspension or expulsion of pregnant teenagers, poor academic performance prior to pregnancy, few child-caring alternatives, inadequate support from families, peers and the school environment, as well as the social stigma of being a teenage mother (Department of Basic Education, 2010:42). Furthermore some parents may not send girls to school because they consider the benefits of education for girls to be limited and the cost of sending them to school to be unnecessary for the family to carry (Department of Basic Education, 2010:42).

The South African Schools Act 84 of 1996 requires parents to ensure that their children attend school from the first school day of the year in which they turn 7, until the last school day of the year in which they turn 15, or the end of Grade 9, whichever comes first. The law compels every school-going child to be at school irrespective of whether she is pregnant or not. In other words there should be no discrimination in terms of gender or pregnancy. However, there are challenges facing the management of schools when a learner becomes pregnant. It is true that there is a policy that deals with pregnant learners; the challenge is whether the SMTs have been trained or not. While pregnancy may be the termination point most directly associated with dropping out, it is often not the cause. Girls who perform poorly at school are more likely to drop out of school, experience early fertility and be less likely to return to school following pregnancy. In fact, South African data indicates that dropping out often precedes pregnancy (Department of Education, 2007:43).

While South African legislation prevents young mothers from being discriminated against at school, there is still significant evidence to suggest that pregnant school-goers are asked to leave school during their pregnancies. This is possibly because young pregnant women are perceived as a bad influence on other young women. Furthermore, the Department of Education's Policy on Measures for the Prevention and Management of Learner Pregnancy make it possible for educators to 'request' that learners take a leave of absence for up to two years (Macleod \& Tracy, 2009:1415). This policy negates what the South African Constitution says about every child having the right to education; on the other hand it puts the SMTs in a catch-22 situation. Two years is a long time and by the time the learner comes back to school she would have forgotten almost all that she had learned. On the other hand how does one tell a pregnant learner to leave school and stay home for two years; hence there is frustration on the part of principals. Some principals of schools tend to summon the parents of pregnant learners to come and stay at school in case there are complications regarding their children which are not part of the policy. Challenges that SMTs encounter force them to violate policy deliberately or not. In this study the researcher wishes to discover how SMTs perceive this policy on measures for the prevention and management of teenage pregnancy. 


\section{Teenage pregnancy in schooling versus MDGs and EFA goals}

The Bill of Rights in the South African Constitution (RSA, 1996a) stipulates that "everyone has the right to a basic education, including adult basic education; and further education, which the State, through reasonable measures, must make progressively available and accessible" (Department of Basic Education, 2010:10). In terms of the South African Schools Act (SASA) (RSA 1996b), education for learners is compulsory for children turning 7 until the age of 15 or Grade 9 (whichever comes first). Although education is not compulsory for learners beyond Grade 9, the government encourages learners to enrol beyond Grade 9 and no learner who wishes to continue to Grade 12 is denied access to schooling (Department of Basic Education 2010:10).

The 2000 Dakar Framework for Action sets out six Education For All (EFA) goals. The goals are global in nature. Via a process of consultation with stakeholders and with the assistance of the wider international community, as well as EFA follow-up mechanisms, countries were expected to set their own goals, intermediate targets and timelines within existing or new national education plans (UNESCO, 2000). The six EFA goals are as follows:

- Goal 1: Expanding and improving comprehensive early childhood care and education, especially for the most vulnerable and disadvantaged children.

- Goal 2: Ensuring that by 2015, all children, particularly females, children in difficult circumstances and those belonging to ethnic minorities, have access to a completely free and compulsory primary education of good quality.

- Goal 3: Ensuring that the learning needs of all young people and adults are met via equitable access to appropriate learning and life skills programmes.

- Goal 4: Achieving a 50\% improvement in levels of adult literacy by 2015, especially for women, and equitable access to basic and continuing education for all adults.

- Goal 5: Eliminating gender disparities in primary and secondary education by 2015 , and achieving gender equality in education by 2015, with the focus on ensuring females' full and equal access to, and achievement in basic education of, good quality.

- Goal 6: Improving all aspects of the quality of education and ensuring excellence for all, so that recognised and measurable learning outcomes are achieved by all - especially in literacy, numeracy and essential life skills (Department of Basic Education 2010:8-9).

While EFA goal number 2 ensures that by 2015 all children, females in particular, should have access to free and compulsory education, the Department of Basic Education (2010:42) reports that pregnancy and teenage mothers constitute major causes of secondary school dropouts for girls. It seems as if it will be a big challenge to attain this goal because those learners that are mostly needed at school are dropping out because of pregnancy. Even though there are policies to deal with pregnant learners, principals are doing little to emphasise schooling when a learner becomes pregnant; instead they are encouraging learners to leave school. This argument is supported by Majangaza's (2011) report that a Transkei principal who expelled two pregnant learners from his school last year has again defied orders from the education authorities by again expelling pregnant learners.

Millenium development goal (MDG) number 2 focuses on achieving universal primary education. According to the Commission for Gender Equality's report (2010:57), studies have shown that girls tend to drop out earlier than boys as a result of numerous socioeconomic factors, such as teenage pregnancy, lack of access to safe transport, domestic responsibilities, and being orphaned as a result of their parents dying of HIV and AIDS. Education is central to the development of young people as it prepares them for the world of work and for life. In line with global trends, it is encouraging to note that young people in South Africa are spending more years acquiring the requisite levels of education. There are, however, various socioeconomic factors which impede learners' education process and cause them to drop out of schooling, such as teenage pregnancy and poverty (Commission for Gender Equality, 2010:62-63).

The report of the Commission for Gender Equality (2010:63) states that in 2008, the Department of Education in collaboration with the United Nations Children's Fund (UNICEF) commissioned the Human Sciences Research Council to conduct a study on the prevalence of learner pregnancy in South African schools. The study revealed the following:

- $\quad$ There was an increase in learner pregnancies between 2004 and 2008.

- Provincial trends show a concentration of learner pregnancies in the predominantly rural Eastern Cape, KwaZulu-Natal and Limpopo provinces. 
- Learner pregnancies are predominant in schools that are poorly resourced, those located in poor neighbourhoods, those schools having no fees and those located on land independently owned (farm schools), as well as in schools that involve considerable age mixing (combined schools). Pregnancy rates are lower in specialised schools.

\section{Conclusion}

SMTs of schools face the challenge of learner pregnancies on a daily basis and they are required by law and policy to keep the pregnant learner at school. Despite the presence of the Constitution and the policy, principals continue to expel pregnant learners from schools. The Department of Basic Education should come up with clear guidelines on how to manage learner pregnancy at school and the SMTs should be trained in this regard.

\section{References}

AFP (2011). South Africa worries over rising teen pregnancy. France 24, International News 24/7, 07 April. Retrieved from: http://www.france24.com.

Berry, L. \& Hall, K. (2010). HIV and health - Teenage pregnancy. Children's Institute: University of Cape Town.

Bhana, D., Clowes, L., Morrell, R. \& Shefer, T. (2008). Pregnant girls and young parents in South African school. Focus, Agenda 76.

Commission for Gender Equality. (2010). A gendered review of South Africa's implementation of the millennium development goals. September 2010, report.

Department of Basic Education. (2010). Education for All, 2010 country report. South Africa, Pretoria.

Franzcog, J.Q. (20060. Teenage pregnancy. Extreme O and G 8(2), Winter 2006. University of Notre Dame Medical School, Sydney/Melbourne.

Grant, M.J. \& Hallman, K.K. (2008). Pregnancy-related school dropout and prior school performance in KwaZulu-Natal, South Africa. Studies in Family Planning 39(4).

Gustafsson, S. \& Worku, S. (20070. Teenage motherhood and long-run outcomes in South Africa. Tinbergen Institute, University of Amsterdam.

Hall, K. \& Berry, L. (2009). HIV \& AIDS and STI National Strategic Plan 2007-2011: Teenage pregnancy. Children's Institute, University of Cape Town.

Hlungwani, V. (20110. Sex school learners go on the rampage. Sowetan Live, 31 Jan. Retrieved from: http://www.sowetanlive.co.za/news/2011/01/31/sex-school-learners-go-on-the-rampage.

Macleod, C. \& Tracy, T. (2009). Review of South African research and interventions in the development of a policy strategy on teen-aged pregnancy. World Health Organization \& Health Department in South Africa. Grahamstown, Rhodes University.

Majavu, A. (2009). Their lives are gone. Sowetan Live, 07 Sept. Retrieved from:http://www.sowetanlive.co.za/sowetan/archive/2009/09/07/their-lives-are-gone.

Majangaza, S. (2011). Pregnant learners banned. Dispatch. 15 Feb. Retrieved from: http://www.dispatch.co.za

McNeeley, M. (2007). Pregnant and parenting girls. Wisconsin Women's LAW Journal, 22:2.

Mngoma, S. (2010). The teen pregnancy epidemic. The Witness, 26 May. Retrieved from: http://www.witness.co.za.

Moselakgomo, A. \& Khumalo, N. (2011). Preggies high bounces back. Sowetan Live, 07 Jan. http://www.sowetanlive.co.za/news/2011/01/07/preggies-high-bounce-back.

Moselakgomo, A. (2010). School pregnancy shock. Sowetan Live, 21 July. Retrieved from:http://www.sowetan.co.za/news/2010/07/21/school-pregnancy-shock.

Mthethwa, N. (2011). The battle against teenage pregnancy in South Africa. Ethekwini Community Church, 02 June 2012. Retrieved from: http://www.ethekwinicommunitychurch.org.za.

Panday, S., Makiwane,M., Ranchod, C. \& Letsoalo, T. (2009). Teenage pregnancy in South Africa - with a specific focus on schoolgoing learners. HSRC. Pretoria: Department of Basic Education.

Republic of South Africa (RSA). (1996a). Constitution of the Republic of South Africa Act 108 of 1996. Pretoria: Government Printer.

Republic of South Africa. (1996b). South African Schools Act 84 of 1996. Pretoria: Government Printer.

Department of Education. (2007). The Department of Education Policy on Measures for the Prevention and Management of Learner Pregnancy. Pretoria: Government Printer.

Sowetan Editorial. (2011). Huge disgrace.The hidden rot in the education system is rising to the top. Sowetan Live, 26 Jan. Retrieved from: http://www.sowetan.co.za/news.

UNESCO 2000. Education for All: The Year 2000 Assessment Technical Guidelines. Paris: UNESCO.

Zondo, M.S. (2006). The challenges faced by teenage mothers when balancing their child-rearing responsibilities with academic excellence in three secondary schools in Inanda. MEd dissertation, University of KwaZulu-Natal. 